$1-1-1974$

\title{
Economic analysis of controlled atmosphere apple storage
}

Gregory Lee

Robert L. Jack

Follow this and additional works at: https://researchrepository.wvu.edu/ wv_agricultural_and_forestry_experiment_station_bulletins

\section{Digital Commons Citation}

Lee, Gregory and Jack, Robert L., "Economic analysis of controlled atmosphere apple storage" (1974). West Virginia Agricultural and Forestry Experiment Station Bulletins. 634.

https://researchrepository.wvu.edu/wv_agricultural_and_forestry_experiment_station_bulletins/543 @ WVU. It has been accepted for inclusion in West Virginia Agricultural and Forestry Experiment Station Bulletins by an authorized administrator of The Research Repository @ WVU. For more information, please contact ian.harmon@mail.wvu.edu. 
Economic Analysis Of Controlled Atmosphere Apple Storage

Bulletin 634

November 1974

West Virginia University Agricultural Experiment Station

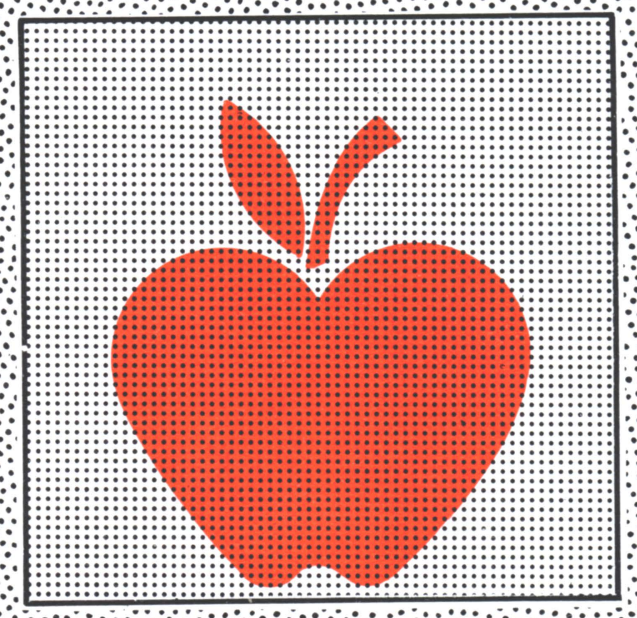




\title{
THE AUTHORS
}

At the time of this study, Gregory Lee was a Graduate Research Assistant in Agricultural Economics; Robert L. Jack is Agricultural Economist.

This bulletin is published as a contribution to the Northeast Regional Marketing Research Project: Future Economic Adjustments in the Marketing of Selected Northeast Fruits and Vegetables (NE-88). The West Virginia research for this publication was supported by both state and regional research funds.

\author{
West Virginia University \\ Agricultural Experiment Station \\ College of Agriculture and Forestry \\ Homer C. Evans, Acting Director \\ Morgantown
}




\title{
Economic Analysis of Controlled Atmosphere Apple Storage
}

\author{
Gregory Lee and Robert L. Jack
}

The 1971 production of apples in the four states included in the Appalachian District totaled 1,338 million pounds and had an estimated total value of $\$ 53,257,000-$ almost 22 per cent of the total national production. (The Appalachian District extends over fruit production areas in Maryland, Pennsylvania, Virginia, and West Virginia.) ${ }^{1}$ District apples are sold during a marketing season which extends from harvest through the following spring. A critical problem for an Appalachian producer is to determine when and how much of the crop to move to market so as to maximize profit.

Appalachian and Washington State apples are competing in the principal eastern market outlets, but seemingly during different time periods. Unloads* , as reported by the Market News Service, show that West Virginia and other Appalachian District states are very important in the Baltimore, Pittsburgh, Philadelphia, and Washington, D.C., markets in the fall and early winter months. From September through December most Appalachian apples are sent to these markets, leaving few to be marketed from January through June (Figure 1).

Washington, and a few other states, take advantage of this situation by shipping apples into Appalachian central markets in increasing quantities as prices rise, corresponding to the decreased District supply (Figure 2). Most of the apples shipped later in the season have been stored in controlled atmosphere (CA) storage units. (The CA process involves refrigeration and lowering the oxygen level in addition to increasing carbon dioxide to specified levels in an air-tight room. This results in much slower ripening than does regular refrigeration storage.) By holding apples until later in the marketing season, Washington producers are able to substantially increase revenues.

\section{Purpose of This Study}

The answer to the following question was sought: Would economic returns to West Virginia and the remaining Appalachian District producers be improved through increased use of controlled atmosphere storage, thereby permitting a more even distribution of apples sold throughout the marketing period?

${ }^{1}$ Marketing Appalachian District Apples, Season Summary-1971 Crop, (Martinsburg, West Virginia: U.S. Department of Agriculture Market News Service, 1971) pp. 4-5.

*An "unload" is a railroad car lot; truck unloads are in railroad car equivalents $(820$ boxes or cartons, each weighing 40-45 lbs.). 


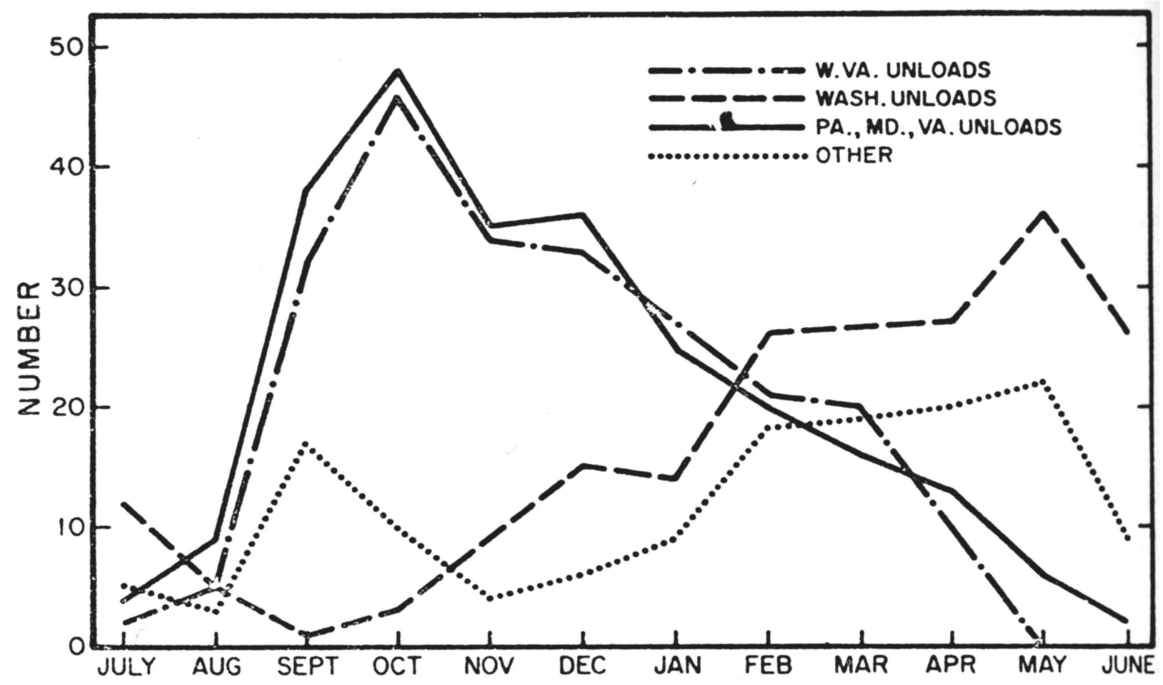

Figure 1. Average number of apple unloads in the Baltimore Market by months, 1965-69. (Source: USDA Market News Service, Fruit and Vegetable Division, Martinsburg, West Virginia)

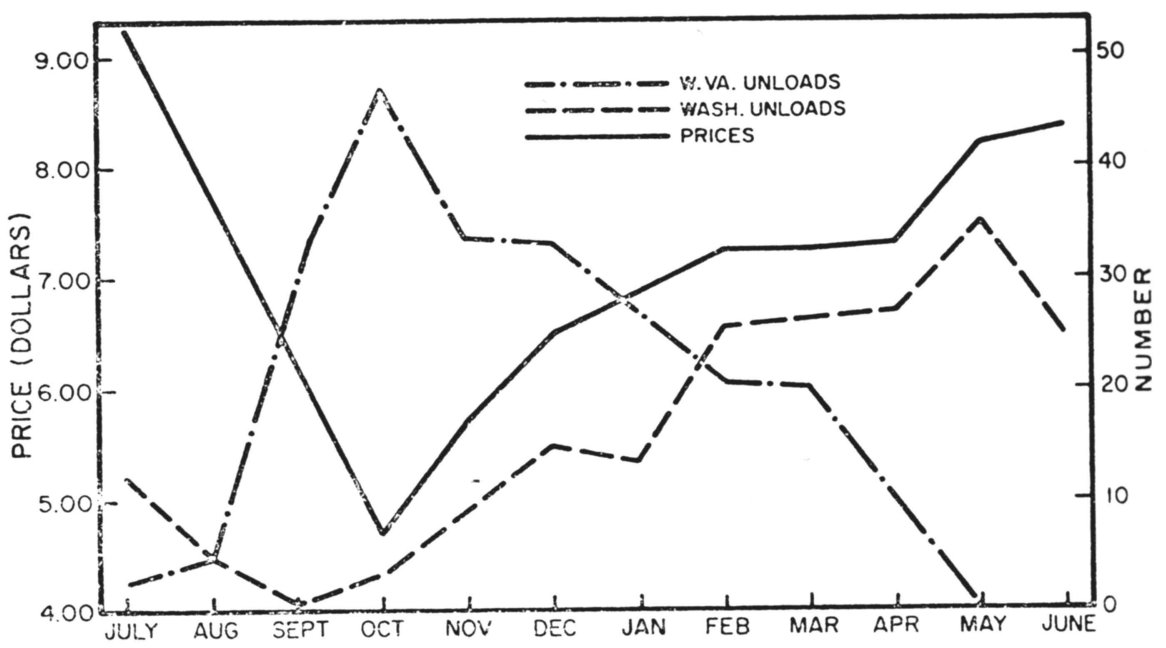

Figure 2. Average number of apple unloads from West Virginia and Washington by month 1965-69 and the 1971 wholesale market price for Red Delicious apples, cartons tray packed, U.S. Extra Fancy-Fancy, 88-125s in the Baltimore Market. (Source: USDA Mar:ket News Service, Fruit and Vegetable Division, Martinsburg, West Virginia) 


\section{Objectives of the Study}

1. To provide a cost analysis of controlled atmosphere storage units.

2. To determine possible price differences that can be obtained in the market by controlled market allocation of a producer's apples through use of controlled atmosphere storage during the market period.

3. To determine the impact on net revenues resulting from crop allocation by use of controlled atmosphere storage by Appalachian producers.

Producers in the Appalachian District have fallen behind other commercial apple producing areas such as Washington, Michigan, and North Carolina in the construction and use of CA storage facilities. Washington State has developed nearly nine million bushels of CA storage capacity since its first unit was installed in 1957. New York and Michigan follow with approximately four million bushels of capacity. ${ }^{2}$ As a constrast, the capacity of Appalachia is approximately one and one-quarter million bushels. CA storage accounted for about 25 per cent of total storage in Washington State in 1970; approximately 11 per cent in Appalachia.

Among the several reasons why CA storage has not been fully adopted by Appalachian producers are the following:

1. Appalachian apples are near a vast eastern market where there are several processing plants and also a large fresh market available to enable total utilization of the crop during a short time span.

2. Many producers do not want to bear the additional risk on capital by holding apples later in the season.

3. Many producers use only seasonal labor and do not want to change labor patterns.

4. Only top-quality apples are desirable for CA storage.

5. Most storage units are old and would be expensive to convert. Most producers would need new facilities altogether since renovation would be nearly as expensive.

6. Lack of information about CA storage and additional revenues that could be generated. ${ }^{3}$

While several of these reasons are personal preferences, the last, and perhaps most critical reason, may be answered by completing the objectives of this study.

${ }^{2}$ Address by D. Loyd Hunter ("CA in the Seventies") before the International Apple Association, Inc., September, 1970.

${ }^{3}$ The author interviewed several producers and storage operators who provided information about their storage operations. 


\section{Procedure}

Determining economic profitability involves two aspects-the cost side and the revenue side. In this study each is to be considered separately and then brought together to determine if there is economic justification leading to the fulfillment of the study purpose.

The cost side is the first area of attention. Since the study deals with differences between regular storage and CA storage costs, other producer expenditures were not considered. An assumption of regular storage was made for a producer in a case study and, in order to develop a reasonable comparison of a new cold storage unit, was used in projecting differences in costs.

The cost analysis included primarily buildings, equipment, labor, utilities, and capital costs in the form of interest. Only one size storage facility of 100,000 bushel capacity was used in the study. This size appears to fit the needs of Appalachian producers fairly well in that smaller producers can increase capacities by this increment. ${ }^{4}$ In any case, estimates of costs for different size units can be derived easily by making adjustments corresponding to refrigeration and CA equipment capabilities.

Costs for each type of storage were estimated for various combinations of regular and CA storage volumes in the 100,000 bushel, palletized storage facility. Costs also were compared at full capacity and less than capacity to determine how this affects average unit costs.

Gross revenues were estimated by taking the average monthly price for Red Delicious apples as reported by the Market News Service and multiplying by the volume packed out of storage. Prices obtained were for Appalachian apples tray packed in combination U.S. Extra Fancy and U.S. Fancy Grade. Revenues were calculated for different situations as a result of varying amounts of apples stored in regular and CA storage.

The Red Delicious variety was selected for this situation study for several reasons. Red Delicious constitutes approximately 20 per cent of the Appalachian District production and is used almost totally for fresh consumption. It is in direct competition with the Delicious apples from Washington State and Michigan which dominate the eastern markets from February to June. Also, complete price information was more attainable for Red Delicious than for other varieties.

The net differences in revenues resulting from use of CA storage were calculated by subtracting storage cost differentials from total revenue differentials for units sold at varying monthly market prices. Thus individuals can draw conclusions as to the feasibility of using CA storage, given a particular situation. Per cent packed out and quality differences for regular and controlled atmosphere storage were assumed to be the same.

${ }^{4}$ Information was supplied by Mr. Randall Reeder, West Virginia Department of Agriculture, from estimates on a new state storage facility at Inwood, West Virginia. 


\section{BASIS FOR ESTIMATING STORAGE COSTS}

Producers' and storage operators' decisions on types of storage facilities to build are likely to be based on available storage and particular need. For various reasons, no two storage facilities are exactly alike or operate at the same cost. However, standards of comparison can be developed upon which storage decisions can be made. Annual storage costs can generally be broken into two categories-overhead or annual fixed costs and operating costs.

\section{Overhead Costs}

Building. Storage structures vary widely in design and initial cost. A building with an approximate storage capacity of 100,000 cartons using pallets was chosen as the size for this study. Two building types were considered-an all-steel structure and a concrete sandwich panel type. The steel structure would be the more expensive of the two and was used as the primary structure in the study since the objective was to evaluate the economic consequences of an option. Each building was equally suited for both regular and controlled atmosphere storage. In addition to the two building options, two refrigeration options, an ammonia type system and a freon system, were considered available to the storage operator. Table 1 provides initial investment cost figures for a storage facility with the steel building and an ammonia system as Option 1. Three other investment options are presented in Appendix Tables 1, 2, and 3. They are:

Option 2-Concrete sandwich panel building with ammonia refrigeration.

Option 3-Concrete sandwich panel building with freon refrigeration.

Option 4-Steel building with freon refrigeration.

Equipment. The major items of equipment include the costs of refrigeration for both the regular and CA storage plus the additional equipment for CA. All other minor equipment necessary was not included in computing storage costs since they were common to both operations and would be charged off as a packing cost.

The anticipated cost of ammonia refrigeration was approximately $\$ 100,000$ completely installed, including a small service building. If freon rather than ammonia were chosen then four freon units for separate rooms with 25,000 carton capacity would cost about $\$ 75,000$ installed. Personal preference and serviceability would be the most significant factors in choosing between the two systems.

CA equipment is available from several different companies which build and service refrigeration systems and storage equipment. $A$ cost analysis and description of several types of systems was done by Gurevitz and Pflug ${ }^{5}$ to serve

${ }^{5}$ David Gurevitz and I. J. Pflug, Costs of Oxygen and Carbon Dioxide Control Systems For Controlled Atmosphere Storages, Michigan Quarterly Bulletin, Volume 50, No. 4 (East Lansing, Michigan: Michigan State University, May, 1968) pp. 458-479. 


\section{TABLE 1}

Initital investment costs for a 100,000 carton regular and CA storage facility -Option 1-steel building and ammonia refrigeration ${ }^{\mathrm{a}}$

\begin{tabular}{lrr}
\hline \hline Item & $\begin{array}{r}\text { Regular } \\
\text { Storage }^{\text {b }}\end{array}$ & $\begin{array}{c}\text { CA } \\
\text { Storage }^{\text {b }}\end{array}$ \\
\hline Site preparation & $\$ 35,000$ & $\$ 35,000$ \\
Steel Bldg. 24' x 100' x 120' & 36,000 & 36,000 \\
$\quad$ Installation charges & 12,000 & 12,000 \\
$\quad$ Urethane insultation & 22,000 & 22,000 \\
Refrigeration (ammonia) with service bldg. & 100,000 & 100,000 \\
Interior walls, doors, and plumbing & 10,000 & 10,000 \\
Electrical installation & 25,000 & 25,000 \\
CA equipment (installed) & & 24,000 \\
\hline
\end{tabular}

\footnotetext{
anvestment costs using different building and refrigeration units are listed in Appendix Tables 1, 2, and 3.

${ }^{b}$ Cost data supplied by the West Virginia Department of Agriculture 1973.
}

as a guide for those interested in various systems for a storage facility. SMB Corporation of Seattle, Washington, ${ }^{6}$ provided operational data on a complete CA system using their Catalytic Oxygen Burner (COB3) and Molecular Sieve Adsorber (MSA8) for use in a CA storage with a capacity of 100,000 cartons. The analysis evaluates costs of storage on the basis of this combination unit with an approximate price of $\$ 24,000$ (Table 1 ).

Depreciation on the storage building was based on a 20 -year life, with no salvage value. Although this seems a relatively short period, changes in technology make the estimate reasonable. Depreciation was calculated using the straight line method with a 10-year life, with no salvage value on both the refrigeration and $\mathrm{CA}$ equipment.

Taxes, Insurance, and Interest. Cost of these items will vary. Some operators may need to borrow more capital or insure at higher levels than others. Taxes and insurance in other studies have been based on operating costs which can vary markedly when size of operation, per cent capacity, and length of storage are

${ }^{6}$ Information supplied by Wells Labberton, SMB Corporation, 2225 Harbor Avenue, Seattle, Washington. 
considered. Therefore, taxes and insurance were calculated on an investment cost basis at a rate of .35 per cent per annum. Interest was assumed to be six per cent based on one-half of the initial investment cost in building and equipment, using previous studies as a guide for determining normal indebtedness.

\section{Operating Costs}

Electricity. Electrical requirements in apple storages are primarily the power needed to operate refrigeration and CA systems. Electrical needs for lights and miscellaneous purposes are minor and need not enter the cost calculations. Requirements were estimated on actual usage by regular storage and by rated capacity usage of CA equipment. Table 2 shows estimated monthly electrical requirements and costs for a 100,000 carton facility operating at full capacity. These estimates were based on a 30-day period of full refrigeration output in which the refrigeration units operated 20 hours per day. Thereafter, units were

\section{TABLE 2}

Estimated monthly requirements and costs of electricity for a 100,000 carton facility for regular and controlled atmosphere storage

\begin{tabular}{|c|c|c|c|c|c|c|}
\hline \multirow[b]{2}{*}{ Months } & \multicolumn{2}{|c|}{$\begin{array}{c}\text { KWH } \\
\text { Requirements }^{\mathrm{a}}\end{array}$} & \multicolumn{2}{|c|}{$\begin{array}{c}\text { Cost } \\
\text { Dollars/Month }\end{array}$} & \multicolumn{2}{|c|}{$\begin{array}{l}\text { Accum. Costs } \\
\text { Dollars/Season }\end{array}$} \\
\hline & Régular & CA & Regular & $\mathrm{Ca}$ & Regular & CA \\
\hline 1 & 70,950 & 93,750 & 816 & 1,078 & 816 & 1,078 \\
\hline 2 & 42,570 & 56,250 & 490 & 647 & 1,306 & 1,725 \\
\hline 3 & 42,570 & 56,250 & 490 & 647 & 1,796 & 2,372 \\
\hline 4 & 42,570 & 56,250 & 490 & 647 & 2,286 & 3,019 \\
\hline 5 & 42,570 & 56,250 & 490 & 647 & 2,776 & 3,666 \\
\hline 6 & & 56,250 & & 647 & & 4,313 \\
\hline 7 & & 56,250 & & 647 & & 4,960 \\
\hline 8 & & 56,250 & & 647 & & 5,607 \\
\hline
\end{tabular}

${ }^{a}$ Electrical requirements were calculated on the basis of a 30-day full capacity period in which the refrigeration units operate 20 hours a day. Thereafter, units were assumed to operate at $60 \%$ of rated capacity. Electricity was calculated at 1.15 cents per $\mathrm{KWH}$ at commercial rates. Refrigeration system used was the ammonia and CA equipment manufactured by the SMB Corporation-COB3 and MSA8. 
assumed to operate at 60 per cent of rated capacity. Electricity cost of 1.15 cents per kilowatt hour was used in the calculations. ${ }^{7}$

Propane. Liquid propane gas (LPG) is used by a catalytic oxygen burner to convert oxygen into carbon dioxide. The amount of propane burned was calculated by using the same levels of capacity operation as was estimated for electrical requirements. LPG was quoted at 33.7 cents per gallon. ${ }^{8}$

Labor. Labor is at times a management problem for nearly all producers and storage operators. Part-time labor is likely to be available only during specific periods, such as harvest and grading time. Some storage operators may not have need for a full-time employee during the storage period.

Estimated actual hours of labor needed for the storage operation alone are given in Table 3. Check time on refrigeration and atmosphere have accounted for a large proportion of the labor requirements in the past. However, with modern facilities and equipment a check time of one hour per day for regular storage and 40 minutes per day for controlled atmosphere were considered sufficient. The wage rate used was two dollars per hour, although this may vary according to location, responsibility, and number of hours worked.

Miscellaneous Expenses. Numerous incidental i iems of expense exist in operating a storage facility. The most significant of these is repair and maintenance of buildings and associated equipment, which were estimated to average about one per cent of the original cost. Most studies use this figure for long term investment in buildings or structures for farm operation. Refrigeration materials, including filters and chemicals, were assigned a flat rate of $\$ 645$ per year based on an ammonia system.

\section{Combined Costs}

Estimated overhead and operating costs are combined in Table 4 to determine the total annual cost of operation for a 100,000 carton regular or CA storage facility. Total seasonal cost of operation was $\$ 34,730$ for regular and $\$ 41,770$ for CA based on 150 days of storage for regular and 240 days for CA. Approximate cost per carton was $\$ .35$ for regular and $\$ .42$ for CA on a seasonal basis.

Storage operators may wish to sell apples at some time before the 150-and 240-day storage period is reached. Under this type of situation it is reasonable to assume that operating costs would be lowered. Table 5 illustrates the cumulative seasonal costs for storing apples at monthly intervals for both regular and CA

${ }^{7}$ Prices were quoted by the Potomac Edison Company of West Virginia, Martinsburg, West Virginia, 1972 rate schedule.

${ }^{8}$ Price quoted by Preston Gas Company, Morgantown, West Virginia, January 4, 1974. 


\section{TABLE 3}

Labor requirements and costs for a 100,000 carton regular and controlled atmosphere storage

\begin{tabular}{lrr}
\hline \hline & \multicolumn{2}{c}{ Labor $^{\mathrm{c}}$} \\
\cline { 2 - 3 } Item & Hours & Dollars \\
\hline Place in storage $^{\mathrm{a}}$ & 750 & 1,500 \\
Preparation, handling and cleaning $^{\mathrm{a}}$ & 430 & 860 \\
Load out of storage $^{\mathrm{a}}$ & 600 & 1,200 \\
Check time $^{\mathrm{b}}$ & & \\
$\quad$ Regular $_{\text {Controlled atmosphere }}$ & 150 & 300 \\
TOTALS $^{\text {Regular }}$ & 160 & 320 \\
Controlled atmosphere & & 3,860 \\
\hline
\end{tabular}

\footnotetext{
${ }^{a}$ Estimates of labor requirements were obtained from: Gene A. Mathia, Costs of Storing North Carolina Apples, Economics Information Report No. 5 (Raleigh, North Carolina: North Carolina State University, 1967) Table 9.

${ }^{b}$ Check time was based on a maximum of 150 days for regular storage and 240 days for CA storage using new facilities and equipment.
}

${ }^{\mathrm{C}}$ The wage rate used was $\$ 2.00$ per hour.

storage. Cost figures were derived with the assumption that all apples would be moved from storage at the end of each month. There is generally a requirement of a minimum storage period of 90 days before apples can be sold as controlled atmosphere storage apples.

All preceding cost figures mentioned have been estimated on use of storage facility option one using the steel building and ammonia refrigeration. Overhead costs for the three other options are given in Appendix Table 4. Operating costs should be similar regardless of the option chosen.

It may not be possible for a storage operator to fill the storage facility to 100 per cent of the carton capacity during any one season. If the storage unit was filled to 50 per cent of capacity the cost per carton for regular storage would be $\$ .63$ and $\$ .73$ for CA. At 75 per cent of capacity the cost per carton would be $\$ .44$ for regular storage and $\$ .52$ for CA storage. These costs were based on the assumption that variable operating items such as labor, electricity, and propane would change according to level of capacity. 


\section{TABLE 4}

Combined costs of storing apples in regular and controlled atmosphere storage facilities with a 100,000 carton capacity

\begin{tabular}{|c|c|c|}
\hline Item & $\begin{array}{l}\text { Regular } \\
\text { Storage }\end{array}$ & $\begin{array}{c}\text { CA } \\
\text { Storage }\end{array}$ \\
\hline \multicolumn{3}{|l|}{ Overhead Costs } \\
\hline Depreciation $^{\mathrm{a}}$ & $\$ 17,000$ & $\$ 19,400$ \\
\hline Taxes and insurance ${ }^{b}$ & 840 & 924 \\
\hline Interest $^{c}$ & 7,200 & 7,920 \\
\hline \multicolumn{3}{|l|}{ Operating Costs } \\
\hline Labor & 3,860 & 3,880 \\
\hline Electricity $^{d}$ & 2,776 & 5,607 \\
\hline Propane $\mathrm{e}^{\mathrm{a}}$ & & 745 \\
\hline Repairs and maintenance ${ }^{f}$ & 2,400 & 2,640 \\
\hline Refrigeration materials $^{g}$ & 654 & 654 \\
\hline TOTAL COSTS & $\$ 34,730$ & $\$ 41,770$ \\
\hline Cost/carton/season & $\$ .35$ & $\$ .42$ \\
\hline
\end{tabular}

${ }^{a}$ Depreciation was calculated using the straight line method assuming a zero salvage value on the basis of 20 year life for building, and a 10 year life for refrigeration equipment and CA equipment.

${ }^{\mathrm{b}}$ Calculated at $.35 \%$ of initial investment.

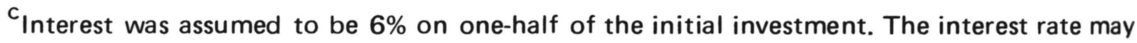
be more for certain agencies.

${ }^{d}$ Based on 150 days for regular storage and 240 days for the controlled atmosphere storage. ${ }^{\mathrm{e}}$ Assuming a maximum 240 days of operation for an SMB Corporation COB3 oxygen burner at 33.7 cents per gallon for LPG.

${ }^{f}$ Calculated at $1 \%$ of original costs.

${ }^{9}$ Based on an ammonia refrigeration system. 


\section{TABLE 5}

Cumulative seasonal costs for storing apples in regular and controlled atmosphere storage facilities with a 100,000 carton capacity

\begin{tabular}{|c|c|c|c|c|}
\hline \multirow{2}{*}{$\begin{array}{l}\text { Months } \\
\text { Stored }\end{array}$} & \multicolumn{2}{|c|}{ Accumulated Cost } & \multicolumn{2}{|c|}{ Cost Per Carton } \\
\hline & Regular & $\overline{C A}$ & Regular & CA \\
\hline 1 & $\$ 32,530$ & $\$ 36,369$ & $\$ .33$ & $\$ .36$ \\
\hline 2 & 33,080 & 37,132 & .33 & .37 \\
\hline 3 & 33,640 & 37,785 & .34 & .38 \\
\hline 4 & 34,180 & 38,518 & .34 & .39 \\
\hline 5 & 34,730 & 39,451 & .35 & .39 \\
\hline 6 & & 40,224 & & .40 \\
\hline 7 & & 40,997 & & .41 \\
\hline 8 & & 41,770 & & .42 \\
\hline
\end{tabular}

\section{ANALYSIS OF ALTERNATIVES}

\section{Market Patterns}

Each producer should use information about seasonal demand and supply to determine the most profitable quantity of apples to store and the optimal periods for movement from storage. One way to gauge supply of a particular variety is to examine total production over a period of time. Table 6 shows the reported production of Red Delicious apples for the United States and the Appalachian District for the years 1968-72. Looking at Appalachian production by itself would not be an accurate indicator of total market supply for a given market since it can be assumed that Red Delicious apples grown anywhere in the United States are a perfect substitute for those grown in Appalachia.

Supply relationships by themselves have little meaning until corresponding prices for apples are obtained. Table 7 gives the average monthly prices for Red Delicious apples F.O.B. at the Baltimore market. Baltimore was chosen as the market base for this study due to extensive sales of Appalachian apples through the Washington-Baltimore markets. Close observation has shown little difference in price of similar quality apples in the two markets.

Prices generally increase from October through May with the exception of the month of January when prices dip slightly over the five-year average. This may be attributed to the post-holiday season when movement of apples decreases. The months of December to February represent the period in which 
most apples are usually taken out of regular storage. Beyond February, however, apples are taken from controlled atmosphere storage in increasing amounts with no apples coming from regular storage by the end of March.

Table 8 illustrates export movement of Appalachian District Red Delicious by month from the continental United States for those apples sold in tray pack cartons over the most recent five-year period. About 87 per cent of the apples sold in this manner were sold by the end of December. April and May prices (Table 7) were quoted for Washington State CA apples due to the fact that just a few Appalachian apples are sold at this time because of the absence of any significant numbers of CA storages in the District. Appalachian producers have sold nearly all of their Red Delicious apples by the time prices have reached their peak. Therefore, an increase in revenues could be realized if a producer were to store more apples during the season for sale in April and May. If indeed this is the case, two general assumptions must be made: the individual producer can control times of sale for his apples in each season; and his major goal is to maximize profit during the season.

The marketing problem thus becomes one of using knowledge of seasonal supply and related prices to allocate sales of apples stored and maximize gross revenues. The growing and harvesting costs are treated as fixed for all apples, therefore only storage costs are relevent to the sales period.

\section{Storage Optimization}

Storage cost estimates under varying conditions of construction and operation for both regular and controlled atmosphere units have been provided. Production, storage movement by months, and prices of Red Delicious apples were presented for a five-year period. By bringing this information together, producer decisions at the individual level can be made to determine the most profitable storage policy.

Since a producer can sell his apples anytime during or after harvest, there are an almost infinite number of storage and sale options available. Limitation of these options is necessary for meaningful study.

The first limitation is the usual maximum holding period of 150 days for regular and $\mathbf{2 4 0}$ days for controlled atmosphere storage. The second limitation is that all apples in a particular storage will be sold at once and at the end of a month. This reduces the number of calculations necessary to determine variable storage costs and total revenues by using the five-year average monthly price.

One important factor of apple storage not previously discussed is the cost of keeping operating capital tied up from the earliest possible sale period (which is harvest) until the actual time of sale. Therefore, an eight per cent yearly interest rate on operating capital has been used to calculate a discounted value of the apples sold monthly. 
TABLE 6

Production of Red Delicious apples in the United States and the Appalachian District, 1968-72

\begin{tabular}{lcc}
\hline \hline Year & Appalachia & United States \\
\hline & & million pounds \\
1968 & 193.9 & $1,390.4$ \\
1969 & 245.8 & $2,093.9$ \\
1970 & 259.1 & $1,915.6$ \\
1971 & 269.0 & $1,789.0$ \\
1972 & 228.1 & $1,735.8$ \\
\hline
\end{tabular}

Source: USDA Market News Service, Fruit and Vegetable Division, Martinsburg, West Virginia.

\section{TABLE 7}

Average monthly F.O.B. prices of Red Delicious apples at the Baltimore market. Cartons tray pack, mostly 88-113s combination Extra Fancy-Fancy

\begin{tabular}{lrrrrrr}
\hline \hline Month & 1972 & 1971 & 1970 & 1969 & 1968 & Average \\
\hline Oct. & $\$ 6.25$ & $\$ 6.30$ & $\$ 5.33$ & $\$ 3.60$ & $\$ 5.92$ & $\$ 5.48$ \\
Nov. & 6.75 & 5.88 & 6.00 & 4.00 & 6.50 &, 5.82 \\
Dec. & 7.00 & 5.85 & 6.12 & 4.00 & 7.25 & 6.04 \\
Jan. & 7.00 & 5.19 & 6.20 & 4.25 & 6.66 & 5.86 \\
Feb. & 7.66 & 5.62 & 5.50 & 4.33 & 7.00 & 6.02 \\
Mar. & 8.43 & 6.75 & 5.75 & 5.75 & 6.00 & 6.54 \\
Apr. $^{\text {a }}$ & 7.94 & 8.10 & 5.95 & 6.88 & 6.68 & 7.11 \\
May $^{\text {a }}$ & 9.44 & 8.38 & 5.83 & 7.50 & 7.45 & 7.72 \\
\hline
\end{tabular}

${ }^{\mathrm{a}}$ Washington State controlled atmosphere.

Source: USDA Market News Service, Fruit and Vegetable Division, Martinsburg, West Virginia.

USDA Market News Service, Fruit and Vegetable Division, Baltimore, Maryland. 
Under these restrictions estimated revenues can be calculated by the following equations:

$$
T G R=S q\left(\frac{1}{1+r t}\right)\left(P_{t}\right)
$$

where: TGR = Total Gross Revenue to storage per length of storage period

Sq = Quantity sold

$r \quad=$ Interest rate per month

$\mathrm{t} \quad=$ Month sold $(1,2,3$. . . etc.) out of storage

$\mathrm{P} \quad=$ Five-year average monthly price

$$
\text { TNR }=\text { TGR }-\mathrm{Ci}
$$

where: TNR $=$ Total Net Revenue to storage per length of storage period

$\mathrm{Ci}=$ Cumulative storage cost per month

Table 9 shows the estimates to regular storage of Red Delicious apples sold in cartons tray packed. Note that the Total Net Revenue to storage and thus net return per carton is highest during the month of December. This would indicate that in an average year a producer would probably receive the most new revenue by selling his apples in December out of regular storage.

\section{TABLE 8}

Appalachian crop export movement of Red Delicious apples in cartons tray pack

\begin{tabular}{lrrrrr}
\hline \hline Month & 1972 & 1971 & 1970 & 1969 & 1968 \\
\hline & & & cartons & \\
Oct. $^{\text {a }}$ & 6,151 & 16,423 & 17,798 & 49,567 & 25,067 \\
Nov. & 8,157 & 11,360 & 23,602 & 36,924 & 8,875 \\
Dec. & 19,922 & 39,582 & 25,904 & 32,634 & $6,399^{\text {b }}$ \\
Jan. & 4,460 & 7,290 & 512 & 9,100 & b \\
Feb. & 3,886 & 4,247 & 2,830 & 3,370 & $1,000^{\text {b }}$ \\
Mar. & 5,029 & 1,890 & 1,980 & 2,800 & 600 \\
TOTALS & 47,605 & 80,792 & 72,626 & 134,395 & 41,941 \\
\hline
\end{tabular}

\footnotetext{
${ }^{\mathrm{a}}$ Includes mid-September shipments.

${ }^{b}$ Export movement curtailed by dock labor dispute.

Source: USDA Market News Service, Fruit and Vegetable Division, Martinsburg, West Virginia.
} 


\section{TABLE 9}

Estimated revenues to regular storage of Red Delicious apples during the regular storage period

\begin{tabular}{|c|c|c|c|c|c|c|c|c|}
\hline Month & $\begin{array}{l}\text { Cartons } \\
\text { Sold }\end{array}$ & Price $^{a}$ & $\begin{array}{l}\text { Discount } \\
\text { Value }^{\mathrm{b}}\end{array}$ & TGR & $\begin{array}{l}\text { Cost of } \\
\text { Storage }^{c}\end{array}$ & TNR & $\begin{array}{l}\text { Net Return } \\
\text { per Carton }\end{array}$ & $\begin{array}{c}\text { Net Revenue } \\
\text { to Storage }\end{array}$ \\
\hline Oct. & 100,000 & $\$ 5.48$ & $\$ .9934$ & $\$ 544,994$ & $\$ 32,530$ & $\$ 512,464$ & $\$ 5.12$ & 0 \\
\hline Nov. & 100,000 & 5.82 & .9868 & 574,318 & 33,080 & 541,238 & 5.41 & 28,774 \\
\hline Dec. & 100,000 & 6.04 & .9804 & 592,162 & 33,640 & 558,522 & 5.58 & 46,058 \\
\hline Jan. & 100,000 & 5.86 & .9740 & 570,764 & 34,180 & 536,584 & 5.36 & 24,120 \\
\hline Feb. & 100,000 & 6.02 & .9677 & 582,555 & 34,730 & 547,825 & 5.47 & 35,361 \\
\hline
\end{tabular}

${ }^{a}$ Based on five-year monthly averages F.O.B. at the Baltimore market.

${ }^{\mathrm{b}}$ Calculated using an $8 \%$ yearly interest rate on operating capital.

${ }^{\mathrm{c}}$ Storage costs based on facilities discussed on pages 5-11. 
Revenues were estimated in the same manner for CA storage and are presented in Table 10. Highest return per carton would be realized if the apples were held until May in CA storage when average net return per carton would be $\$ 6.91$. From these two tables it is most likely that an individual would elect to store all his apples in CA and hold them until May. However, there is no absolute assurance that prices would continue to rise until May.

A producer may choose to minimize his risk by storing part of his crop in regular storage and part in CA storage. Table 11 represents such an allocation on a $50-50$ basis. An amount of 50,000 cartons could be sold during any one month from October through February from regular storage and 50,000 cartons from CA during any one month March through May. Total net revenues would then be the sum of the two sales. The highest total revenue could be obtained from this type of allocation by selling the regular storage apples in December and the CA apples in May. Total Net Revenue would be $\$ 622,962$ from the sale of all 100,000 cartons.

The gain in net revenue from storage was calculated by taking the difference between the October Total Net Revenue and the Total Net Revenue for each of the following months. This represents the Net Revenue to storage that resulted from storing the apples additional months as illustrated in Tables 9, 10, and 11. Sales in January resulted in less revenue than sales in December, as can be seen in each table. Greatest single monthly increase in net revenues occurred during the CA storage period in the month of May when net return per carton increased 53 cents over the previous month. Highest increase in net revenues for a month's storage in regular storage occurred during the month of November.

Very few years can be classified "average" in the apple industry and the producer is probably as much or more interested in the number of years in the long run in which storage would be profitable with each method of storage. The months in which it would have been profitable to store Red Delicious apples in regular and CA storage based on storage cost and price differentials for the years 1968-72 are shown in Table 12. Regular storage would have been profitable all five years. All regular storage apples should have been sold in October in 1971 rather than holding them until December. CA storage would have been profitable four of those five years. The exception was in 1970 when all apples should have been sold in January, which means that no advantage would have been gained by use of CA storage in 1970 since storage operating costs were greater than the price differential for any of the succeeding months. In the other four years apples should have been held until May.

Producers will ultimately have to choose the amount of risk that they may wish to take in storing apples in either regular or CA storage. Profits and losses to storage will be determined as the result of market situations after the storage decision has been made. Table 13 gives estimated net revenues from use of the model storage facility when storing varying combinations of quantities in regular 
TABLE 10

Estimated revenues to controlled atmosphere storage of Red Delicious apples during the controlled atmosphere storage period

\begin{tabular}{|c|c|c|c|c|c|c|c|c|}
\hline Month & $\begin{array}{l}\text { Cartons } \\
\text { Sold }\end{array}$ & Price $^{a}$ & $\begin{array}{l}\text { Discount } \\
\text { Value }^{\mathrm{b}}\end{array}$ & TGR & $\begin{array}{l}\text { Cost of } \\
\text { Storage }\end{array}$ & TNR & $\begin{array}{l}\text { Net Return } \\
\text { per Carton }\end{array}$ & $\begin{array}{c}\text { Net Revenue } \\
\text { to Storage }\end{array}$ \\
\hline Oct. & 100,000 & $\$ 5.48$ & $\$ .9934$ & $\$ 544,994$ & $\$ 36,389$ & $\$ 508,605$ & $\$ 5.09$ & $\$$ \\
\hline Nov. & 100,000 & 5.82 & .9868 & 574,318 & 37,132 & 537,186 & 5.37 & 25,581 \\
\hline Dec. & 100,000 & 6.04 & .9804 & 592,162 & 37,785 & 554,377 & 5.54 & 45,772 \\
\hline Jan. & 100,000 & 5.86 & .9740 & 570,764 & 38,518 & 532,246 & 5.32 & 23,641 \\
\hline Feb. & 100,000 & 6.02 & .9677 & 582,555 & 39,451 & 543,104 & 5.43 & 34,499 \\
\hline Mar. & 100,000 & 6.54 & .9615 & 628,821 & 40,224 & 588,597 & 5.89 & 79,992 \\
\hline Apr. & 100,000 & 7.11 & .9554 & 679,289 & 40,997 & 638,292 & 6.38 & 129,687 \\
\hline May & 100,000 & 7.72 & .9494 & 732,937 & 41,770 & 691,167 & 6.91 & 182,562 \\
\hline
\end{tabular}

${ }^{\mathrm{a}}$ Based on five-year monthly averages F.O.B. at the Baltimore market.

${ }^{b}$ Calculated using an $8 \%$ yearly interest rate on operating capital.

${ }^{\mathrm{c}}$ Storage costs based on facilities discussed on pages 5-11. 


\section{TABLE 11}

Estimated revenues to controlled atmosphere and regular storage of Red Delicious apples allocated to storage on a $\mathbf{5 0 - 5 0}$ basis

\begin{tabular}{|c|c|c|c|c|c|c|c|c|}
\hline Month & $\begin{array}{l}\text { Cartons } \\
\text { Sold }\end{array}$ & Price $^{a}$ & $\begin{array}{l}\text { Discount } \\
\text { Value }^{b}\end{array}$ & TGR & $\begin{array}{l}\text { Storage Cos } \\
\text { Regular }\end{array}$ & $\begin{array}{l}\text { Storage Cost } \\
\text { CA }\end{array}$ & TNR & $\begin{array}{l}\text { Net Revenue } \\
\text { to Storage }\end{array}$ \\
\hline Oct. & 50,000 & $\$ 5.48$ & $\$ .9934$ & $\$ 272,947$ & $\$ 16,265$ & - & $\$ 256,682$ & $\$$ \\
\hline Nov. & 50,000 & 5.82 & .9868 & 287,159 & 16,540 & - & 270,619 & 13,937 \\
\hline Dec. & 50,000 & 6.04 & .9804 & 296,081 & 16,820 & - & 279,261 & 22,579 \\
\hline Jan. & 50,000 & 5.86 & .9740 & 285,382 & 17,090 & - & 268,292 & 11,610 \\
\hline Feb. & 50,000 & 6.02 & .9677 & 291,278 & 17,365 & - & 273,913 & 17,231 \\
\hline Mar. & 50,000 & 6.54 & .9615 & 314,411 & - & $\$ 22,005$ & 292,406 & 35,724 \\
\hline Apr. & 50,000 & 7.11 & .9554 & 339,645 & - & 22,381 & 317,264 & 60,582 \\
\hline May & 50,000 & 7.72 & .9494 & 366,469 & - & 22,768 & 343,701 & 87,019 \\
\hline
\end{tabular}

${ }^{a}$ Based on five-year monthly averages F.O.B. at the Baltimore market.

${ }^{b}$ Calculated using an $8 \%$ yearly interest rate on operating capital.

$\mathrm{c}_{\text {Storage costs based on facilities discussed on pages } 5-11 .}$ 
and CA storage during the season. Prices were based on a five-year average in which all regular storage apples would have been sold in December and all CA apples in May when prices would have been at their peak. Not using the storage at all resulted in a net loss due to overhead and maintenance which totaled $\$ 28,244$ for CA and $\$ 25,040$ for regular storage. The most revenue would be obtained if all apples were stored in CA as long as the average price used were to remain in effect and Total Net Revenue to storage would be $\$ 691,167$.

\section{TABLE 12}

Months in which it would have been profitable to store Red Delicious apples in regular and controlled atmosphere storage based on storage cost and price differentials, 1968-72 ${ }^{\mathrm{a}}$

\begin{tabular}{lrrrrr}
\hline \hline Month & 1972 & 1971 & 1970 & 1969 & 1968 \\
\hline October & XO & XO & XO & XO & XO \\
November & XO & 0 & XO & XO & XO \\
December & XO & 0 & XO & XO & XO \\
January & XO & 0 & XO & XO & 0 \\
February & XO & 0 & & XO & 0 \\
March & 0 & 0 & & 0 & 0 \\
April & 0 & 0 & & 0 & 0 \\
May & 0 & 0 & & 0 & 0 \\
\hline
\end{tabular}

\footnotetext{
$\mathrm{X}=$ Regular storage

$0=$ Controlled atmosphere storage

${ }^{a}$ If the price differential for any succeeding month was greater than the associated storage cost, then the gain in Net Revenue associated with each month(s) additional storage cost was more than sufficient to justify the additional month(s) storage time.
} 


\section{TABLE 13}

Estimated total net revenues to storage when storing varying combinations of quantities in a 100,000 carton regular and CA storage facility ${ }^{a}$

\begin{tabular}{|c|c|c|c|c|c|c|}
\hline & & & $10 c$ & CARTON & $C A$ & \\
\hline & & 0 & 25 & 50 & 75 & 100 \\
\hline & & $\$-28,244$ & & & & \\
\hline & 0 & $\$-24,040$ & $\$ 149,288$ & $\$ 329,969$ & $\$ 549,703$ & $\$ 691,167$ \\
\hline 인 & 25 & 115,232 & 295,824 & 476,417 & 657,010 & $x$ \\
\hline త 이 & 50 & 264,580 & 442,359 & 622,962 & $x$ & $x$ \\
\hline & 75 & 411,121 & 588,895 & $x$ & $x$ & $x$ \\
\hline & 100 & 558,522 & $x$ & $x$ & $x$ & $x$ \\
\hline
\end{tabular}

${ }^{a}$ Regular storage apples sold in December and CA apples sold in May when prices for Red Delicious apples were highest over a five-year period. Storage costs were calculated on the basis of load capacity and months stored.

\section{SUMMARY, CONCLUSIONS, LIMITATIONS, AND IMPLICATIONS}

\section{Summary}

The purpose of this study was to determine whether economic returns to Appalachian District apple producers could be improved by increased use of controlled atmosphere (CA) storage for apples sold in the fresh market.

Estimates of storage costs were obtained from a cost analysis which dealt primarily with building, equipment, labor, utilities, and capital costs in the form of interest. The model storage facility assumed in the study had a capacity of 100,000 cartons. Investment and operating costs were estimated for regular and controlled atmosphere storages and also for combinations of both in the same storage facility.

Gross revenues were estimated by taking the average monthly price for Red Delicious apples as reported for the Baltimore Market by the Market News Service. Prices obtained were for combination U.S. Extra Fancy and U.S. Fancy Grade. Revenues were calculated for different alternatives as a result of selling varying amounts of apples stored in regular and CA storage.

Net revenues were calculated by subtracting storage costs from gross revenues from apples sold from both regular and CA storage. The value of $C A$ storage was determined by comparing net revenues from use of each storage alternative. 
Controlled atmosphere storage was found to be profitable four of the five years for which average monthly prices were obtained. This was determined by subtracting storage cost differentials from price differentials at the time of sale. During those four years in which CA was determined profitable an average increase in annual net revenue of $\$ 132,645$ could have been achieved over regular storage of 100,000 cartons.

Seasonal cost of storage was estimated to be 35 cents per carton for regular storage and 42 cents per carton for CA storage. These figures were based on 150 days of storage for regular and 240 days for CA.

The average monthly price per carton for a five-year period was highest (\$6.04) for regular storage apples during the month of December. Controlled atmosphere apples averaged $\$ 7.72$ per carton during the month of May. This represented an increase of $\$ 1.68$ per carton for CA apples over regular storage apples.

\section{Conclusions}

Information provided in the preceding sections provides a basis for economic comparison of controlled atmosphere storage and regular storage for an individual firm. The price data obtained for Red Delicious apples for 1968-72 in the Baltimore Market and the analysis of hypothesized storage costs indicate that net revenues could be substantially increased through use of CA storage.

Producers make storage decisions at harvest time. Under the hypothetical situation where a producer chose to store all 100,000 cartons in CA at harvest rather than in regular storage there would be an estimated $\$ 132,645$ addition to net revenue, assuming an "average" year.

Occasionally it would not be profitable to store fresh apples in CA in the Appalachian District. A producer who theorizes prices will not rise through May after making his initial commitment to storage may possibly choose to sell his apples in December. He could then expect a loss due to the investment and operating costs of CA over that of regular storage to be about $\$ 4,145$. With a total storage of 100,000 cartons, this loss might be considered minimal. Conceivably, one very profitable year from CA storage would more than offset such a loss for three or four successive years. However, an even more positive aspect is the flexibility of the storage facility itself. Producers could considerably reduce the risk in CA storage by allocating only a portion of the apples stored to $\mathrm{CA}$ rather than all of them. The loss or gain incurred through use of CA would thus be reduced for any given season.

\section{Limitations}

This study was based on hypothetical situations for an individual producer with given historical market data and up-to-date information for formulating 
storage costs. Using this approach made it necessary to place certain limitations on data and storage options.

Specific limitations to this study were:

1. Only one variety, Red Delicious was considered to be stored and sold in the fresh market. Price and market patterns for other varieties may be different in the Appalachian District. An individual producer may wish to store more than one variety in the same storage facility. Conflict in marketing patterns for these varieties may create problems in moving apples out of CA storages.

2. Economies of scale were evident in previous studies for both regular and controlled atmosphere storages. A facility having a capacity of 100,000 cartons was used for this entire study. However, an indication of possible economies in scale can be gauged from cited works.

3. Comparisons of cost for regular and CA storages were based on the assumption of a new storage facility being necessary in each case. Many producers may not need to build new storages for conversion to controlled atmosphere; they could possibly use existing regular storage facilities. Other producers may consider renovation of existing structures too costly. In either case, cost of operation may be considerably different.

4. Appalachian District Red Delicious apples were considered to be as equally preferred by consumers as any other Red Delicious apples marketed. This means that one price would be commanded by both Appalachian and Washington apples as was assumed in the Baltimore Market price data used. This assumption may or may not hold true. Even under these limitations a producer should be able to base decisions on the information supplied, with due consideration and adjustments for his particular storage operation.

\section{Implications}

There has been a period of extensive growth in the controlled atmosphere storage of apples over the past 15 years. As a result, the consumer is able to purchase apples for fresh consumption in all seasons without sacrificing quality. The demand exhibited during the off-season keeps the price of apples high in the spring and summer months. Until the volume of sales increases sufficiently to suppress prices during this period, continued growth in CA storages can be expected in the eastern United States.

This study has indicated that it would be profitable for a single Appalachian District producer to consider converting to CA storage. No single seller has influence on the average level of prices. However, if a large number of producers in the District converted to CA storage there could be a considerable effect on market prices. This study did not attempt to estimate the impact that additional CA storage in the District would have on the shipping patterns of producers outside of the region or the resulting effect of altered shipping patterns on price 
ot apples in the eastern markets. What is best for an individual producer may not be best for the entire District as a whole.

Obviously, some study of demand elasticity and optimal allocation is necessary before industry-wide recommendations of benefit can be made to the producers. Previous studies have been made in some specific areas. Ben-David and Tomek $^{9}$ developed seasonal demand equations for New York State apples for the years 1960-1963. They believed that optimal allocation of apples would have shown more apples sold during the harvest and CA storage periods and less sold during the regular storage period. A similar study at Michigan State was made by Pasour and Gustafson ${ }^{10}$ in which they concluded that demand was most elastic in the CA storage period.

General changes have taken place in the apple industry in the last decade since these cited studies were conducted. A study of demand elasticity for Appalachian apples could shed considerable light on possible changes in market prices and shipping patterns that would take place in the eastern markets as a result of increased use of CA storage in the Appalachian District. Optimal allocation of the crop could then be reasonably estimated and changes, if necessary, could be made in the present allocation of District apples in the fresh market.

${ }^{9}$ Shaul Ben-David and William G. Tomek, Storing and Marketing New York State Apples, Based on Intraseasonal Demand Relationships, Cornell University Experiment Station Bulletin No. 1007 (Ithaca, New York: New York State College of Agriculture, 1965) p. 16.

${ }^{10}$ E. C. Pasour, Jr. and Robert L. Gustafson, Intraseasonal Supply and Demand Functions for Apples, Agricultural Experiment Station Research Bulletin No. 10 (East Lansing, Michigan: Michigan State University, 1966) p. 48. 


\section{BIBLIOGRAPHY}

Ben-David, Shaul and William G. Tomek. Storing and Marketing New York State Apples, Based on Intraseasonal Demand Relationships. Cornell University Experiment Station Bulletin No. 1007. Ithaca, New York: New York State College of Agriculture, 1965.

Dalrymple, Dana G. The Development of Controlled Atmosphere Storage of Fruit. Washington, D.C.: Federal Extension Service, U.S. Department of Agriculture, 1967.

Ed Cook. Personal Interview. September 12, 1973.

- Fresh Fruit and Vegetable Wholesale Market Prices-Baltimore. Baltimore, Maryland: U.S. Department of Agriculture Market News Service, 1968-1972.

- Fresh Fruit and Vegetable Wholesale Market Prices-Washington, D.C. Washington, D.C.: U.S. Department of Agriculture Market News Service, 1968-1972.

Greig, W. Smith and A. Desmond O'Rourke. Apple Packing Costs In Washington, 1971: An Economic-Engineering Analysis. Washington Agricultural Experiment Station Bulletin No. 755. Pullman, Washington: Washington State University, 1972.

Gurevitz, David and I. J. Pflug. Costs of Oxygen and Carbon Dioxide Control Systems for Controlled Atmosphere Storages. Michigan Quarterly Bulletin, Volume 50, No. 4. East Lansing, Michigan: Michigan State University, May, 1968.

Henderson, Peter L. Measurement of the Rate of Movement of Apples into Consumption and Factors Associated with the Movement of Apples in Retail Food Stores. Virginia Agricultural Experiment Station Bulletin No. 129. Blacksburg, Virginia: Virginia Polytechnic Institute, January, 1957.

Hunter, D. Loyd. "CA In The Seventies." Address before the International Apple Association, Inc. September, 1970.

Kelsey, Myron, and others. Economics of Apple Production in Southwestern Michigan. Agricultural Economics Report No. 184. East Lansing, Michigan: Michigan State University, 1971.

Kenneth McDonald. Personal interview. September 12, 1973.

Mathia, Gene A. Costs of Storing North Carolina Apples. Economics Information Report No. 5, Department of Economics. Raleigh, North Carolina: North Carolina State University, 1967.

Mathia, Gene A. and E. C. Pasour, Jr. An Analysis of Apple Marketing and Storage: North Carolina Market Area. Economics Research Report No. 6, 
Department of Economics. Raleigh, North Carolina: North Carolina State University, 1968.

- Marketing Appalachian District Apples, Season Summaries. Martinsburg, West Virginia: U.S. Department of Agriculture Market News Service, 1968-1972.

Moffett, R. E., and others. Economic Benefits of Optimum Intraseasonal Allocation of New England-New York Mclntosh Apples. Agricultural Experiment Station Bulletin No. 394. Storrs, Connecticut: The University of Conneticut, June, 1966.

J'Rourke, A. Desmond, and others. Apple Marketing Research In The Seventies. Agricultural Experiment Station Bulletin No. 754. Pullman, Washington: Washington State University, April, 1972.

Pasour, E. C., Jr. and Robert L. Gustafson. Intraseasonal Supply and Demand Functions for Apples. Agricultural Experiment Station Research Bulletin No. 10. East Lansing, Michigan: Michigan State University, 1966.

Jodany, Joseph C. and Robert W. Bohall. Regional Costs of Harvesting, Storing and Packing Apples. Economic Research Service Bulletin No. 496, Marketing Economics Division, U.S. Department of Agriculture. Washington, D.C.: U.S. Government Printing Office, November, 1971.

Potomac Edison Company of West Virginia. General Service Rate Schedule "C-A". Martinsburg, West Virginia, 1972.

Price, D. W. Intraseasonal Demand, Supply, and Allocation of Washington Apples. Agricultural Experiment Station Technical Bulletin No. 75. Pullman, Washington: Washington State University, March, 1973.

Randolph Ewers. Personal interview. January 30, 1973.

Randall Reeder. Personal interview and acquisition of data from the West Virginia Department of Agriculture. March 9, 1973.

Thompson, John C., Jr. Apple Storage Costs In New York State. Agricultural Economics Research Bulletin No. 87. Ithaca, New York: Cornell University, 1962.

Wells Labberton. Supplied data on SMB Corporation equipment for generation of controlled atmospheres. Seattle, Washington. 1973. 
[Blank Page in Original Bulletin] 


\section{APPENDIX TABLE 1}

Initital investment costs for a 100,000 carton regular and CA storage facility-Option 2-concrete building and ammonia refrigeration

\begin{tabular}{lrr}
\hline \hline Item & $\begin{array}{l}\text { Regular } \\
\text { Storage }\end{array}$ & $\begin{array}{c}\text { CA } \\
\text { Storage }\end{array}$ \\
\hline $\begin{array}{l}\text { Site preparation } \\
\begin{array}{l}\text { Pre-stressed concrete bldg. } \\
\text { with insulated sandwich panels }\end{array}\end{array}$ & $\$ 35,000$ & $\$ 35,000$ \\
$\begin{array}{l}\text { Installation of building } \\
\text { Refrigeration (ammonia) including }\end{array}$ & 56,000 & 56,000 \\
$\quad$ service building & 12,000 & 12,000 \\
Electrical installation & 100,000 & 100,000 \\
Interior walls, doors, and plumbing & 25,000 & 25,000 \\
CA equipment (installed) & 10,000 & 10,000 \\
\hline TOTALS & $\$ 238,000$ & $\$ 262,000$ \\
\hline
\end{tabular}

\section{APPENDIX TABLE 2}

Initial investment costs for a $\mathbf{1 0 0 , 0 0 0}$ carton regular and CA storage facility-Option 3-concrete building and freon refrigeration

\begin{tabular}{lcc}
\hline \hline Item & $\begin{array}{l}\text { Regular } \\
\text { Storage }\end{array}$ & $\begin{array}{c}\text { CA } \\
\text { Storage }\end{array}$ \\
\hline Site preparation & $\$ 35,000$ & $\$ 35,000$ \\
$\begin{array}{l}\text { Pre-stressed concrete bldg. } \\
\text { with insulated sandwich panels }\end{array}$ & 56,000 & 56,000 \\
$\quad$ Installation of building & 12,000 & 12,000 \\
Refrigeration (freon) including service building & 75,000 & 75,000 \\
Electrical installation & 25,000 & 25,000 \\
Interior walls, doors, and plumbing & 10,000 & 10,000 \\
CA equipment (installed) & & 24,000 \\
\hline TOTALS & $\$ 213,000$ & $\$ 237,000$
\end{tabular}


Initial investment costs for a 100,000 carton regular and CA storage facility-Option 4-steel building and freon refrigeration

\begin{tabular}{lrr}
\hline \hline Item & $\begin{array}{l}\text { Regular } \\
\text { Storage }\end{array}$ & $\begin{array}{c}\text { CA } \\
\text { Storage }\end{array}$ \\
\hline Site preparation & $\$ 35,000$ & $\$ 35,000$ \\
Butler steel bldg. 24' X 100' X 120' & 36,000 & 36,000 \\
$\quad$ Installation charges & 12,000 & 12,000 \\
$\quad$ Urethane insulation & 22,000 & 22,000 \\
Refrigeration (freon) with service building & 75,000 & 75,000 \\
Interior walls, doors, and plumbing & 10,000 & 10,000 \\
Electrical installation & 25,000 & 25,000 \\
CA equipment (installed) & & 24,000 \\
\hline TOTALS & $\$ 215,000$ & $\$ 239,000$ \\
\hline
\end{tabular}

\section{APPENDIX TABLE 4}

Annual overhead costs for storage building and equipment Options 2, 3, and 4

\begin{tabular}{|c|c|c|}
\hline Item & $\begin{array}{l}\text { Regular } \\
\text { Storage }\end{array}$ & $\begin{array}{c}\text { CA } \\
\text { Storage }\end{array}$ \\
\hline \multicolumn{3}{|l|}{ Option 2} \\
\hline Depreciation $^{a}$ & $\$ 16,900$ & $\$ 19,300$ \\
\hline Taxes and insurance ${ }^{\mathrm{b}}$ & 833 & 917 \\
\hline Interest $^{\mathrm{c}}$ & 7,140 & 7,860 \\
\hline \multicolumn{3}{|l|}{ Option 3} \\
\hline Depreciation & $\$ 14,400$ & $\$ 16,800$ \\
\hline Taxes and insurance & 745 & 829 \\
\hline Interest & 6,390 & 7,110 \\
\hline \multicolumn{3}{|l|}{ Option 4} \\
\hline Depreciation & $\$ 14,500$ & $\$ 16,900$ \\
\hline Taxes and insurance & 752 & 836 \\
\hline Interest & 6,450 & 7,080 \\
\hline
\end{tabular}

${ }^{a}$ Depreciation was calculated using the straight line method assuming a zero salvage value on the basis of 20 year life on building, and a 10 year life on refrigeration equipment and controlled atmosphere equipment.

${ }^{\mathrm{b}}$ Calculated at $.35 \%$ of initial investment.

${ }^{c}$ Interest was assumed to be $6 \%$ on one-half of the initial investment. 